\title{
Serramorpbus, a new genus of Erotylidae from Eocene amber (Coleoptera: Clavicornia) from Late Eocene Bitterfeldian Amber
}

\author{
Serramorpbus, новый род ископаемых жкуков-грибовиков \\ (Coleoptera: Clavicornia: Erotylidae) из саксонского янтаря
}

\author{
G.Yu. Lyubarsky ${ }^{1}$, E.E. Perkovsky ${ }^{2}$ \\ Г.Ю. Аюбарский ${ }^{1}$, Е.Э. Перковский ${ }^{2}$
}

\footnotetext{
${ }^{1}$ Zoological Museum, Moscow Lomonosov State University, Bol'shya Nikitskaya 2, Moscow 125009, Russia. E-mail: 1georgy@rambler.ru Зоологический музей, Московский государственный университет им. М.В. Ломоносова, Большая Никитская ул. 2 , Москва 125009, Россия.

${ }^{2}$ Schmalhausen Institute of Zoology, Bogdan Chmielnitski str. 15, Kiev 01601, Ukraine. E-mail: perkovsk@gmail.com
}

KEY WORDS: Erotylidae, Serramorphus, taxonomy, Late Eocene, Bitterfeld amber.

КЛЮЧЕВЫЕ СЛОВА: Erotylidae, Serramorphus, таксономия, поздний эоцен, саксонский янтарь.

ABSTRACT. Based on a fossil specimen from the Late Eocene Bitterfeld amber (Germany, Bitterfeld), the Eocene species and genus Serramorphus rasnitsyni gen.n., sp.n., is described. The new genus is similar to the extant genera Acryptophagus Grouvelle, 1919, Thallisella Crotch, 1875, Platoberus Sharp, 1900, differing in basal groove of pronotum broad, supraocular line absent, pronotal callosity present. The genus Serramorphus is fourth monotypic genus of beetles, known only from Bitterfeld, and the second one - with tropic relationships.

РЕЗЮМЕ. Из позднеэоценового саксонского янтаря (Германия, Биттерфельд) описан Serramorphus rasnitsyni gen.n., sp.n. Новый род наиболее близок к современным родам Acryptophagus Grouvelle, 1919, Thallisella Crotch, 1875, Platoberus Sharp, 1900 и отличается от них наличием широкого вдавления у основания переднеспинки, отсутствием супраокулярной линии, наличием выростов на передних углах переднеспинки. Род Serramorphus - четвёртый род жуков, известный только из Биттерфельда и второй из них - с тропическими связями.

\section{Introduction}

The family Erotylidae is a group of small and medium size beetles with about 3200 described species in about 280 genera, represented in all biogeographic realms except Antarctica [Węgrzynowicz, 2002, 2007; Leschen, 2003]. The classification of the family was most recently revised by Leschen [Leschen, Wegrzynowicz, 1998; Leschen, 2003]. The family Erotylidae includes six subfamilies (Xenoscelinae, Pharaxonothinae, Loberinae, Languriinae, Cryptophilinae, and Erotylinae).

Biology of Erotylidae remains very poorly known, shortly referred in Lyubarsky, Perkovsky [2012], detailed data in Leschen [2003, 2006; Leschen, Buckley,
2007]. Subfamily Erotylinae is mostly mycophagous, while subfamily Languriinae includes phytophagous species. Other subfamilies (Xenoscelinae, Pharaxonothinae, Loberinae, Cryptophilinae) are predominantly mycophagous, some genera are phytophagous or saprophagous, and some species of Xenocryptus, Pharaxonotha, and Hapalips have been found feeding on the pollen of cycads [Windsor et al., 1999; Leschen, Buckley, 2007].

The relationship of Erotylidae with mushrooms is very difficult. The erotylid clade has experienced at least one evolutionary transition from mycophagy to phytophagy, three transitions from Aphyllophorales hosts to Euagarics, and one transition from Euagarics hosts to Mucorales (Zygomycetes) [Robertson et al., 2004].

\section{Palaeontological data}

Palaeontological data concerning the family Erotylidae were reported by Wegrzynowicz [2002]. A few species of the genera Tritoma and Dacne have been described from Dominican amber, as well as some Cryptophilus, Dacne, Tritoma (Baltic amber) and Erotylus (copal) [Poinar, 1992; Skelley, 1997; Spahr, 1981a,b]. A new species of Triplax is described from Bitterfeldian amber [Alexeev, 2014]. The genus Xenohimatium have been described from Rovno amber (Ukraine) [Lyubarsky, Perkovsky, 2012]. This genus related to subfamily Xenoscelinae. Besides that, another one genus related to subfamily Xenoscelinae it just described [Lyubarsky et al., 2016]. Palaeontological data concerning the subfamily Pharaxonothinae are not available. A pair of elytra of Erotylidae are finding in shales of an Eocene lake at Quilchena, British Columbia [Archibald, Mathewes, 2000]. Erotylidae has been found in Lower Cretaceous Lebanese amber [Kirejtshuk, Azar, 2013].

The new genus was found in collection of Christel and Hans Werner Hoffeins (CCHH). 
Photographs were taken at the Schmalhausen Institute of Zoology (Kiev) by the Vitaly Yu. Nazarenko and second author at the microscope Leica MZ 16.

\section{Identification of the fossil}

This specimen is apparently refers to the tribe Thallisellini Sen Gupta, 1968 [characters of Thallisellini by Leschen, 2003]: antennal insertion hidden in dorsal view; antennal club 3-segmented; supraocular line absent; anterior angles of pronotum well developed; procoxal cavity open behind; tibial spurs poorly developed, tarsal shelf absent. The tribe Thallisellini included genera (all Neotropical) Acryptophagus (1 species), Platoberus (10 species), Pseudhapalips (1 species), Thallisella (13 species).

\section{Taxonomy}

\author{
Order Coleoptera \\ Superfamily Cucujoidea Latreille, 1802 \\ Family Erotylidae Latreille, 1802 \\ Subfamily Languriinae Crotch, 1873 \\ Tribe Thallisellini Sen Gupta, 1968
}

\section{Serramorphus gen.n.} Figs 1-4.

Type species: Serramorphus rasnitsyni sp.n.

ETYMOLOGY. The genus name is grammatically masculine. The form of pronotum of the genus is strongly serrated and similar to pronotum at Henotimorphus Lyubarsky, 1987 (Cryptophagidae), therefore the name it reminds us of this.

DIAGNOSIS. Frontoclypeal suture present. Genal spines present. Antennal insertion not exposed in dorsal view. Antenna with 11 antennomeres and a 3-segmented club. Antenna long and reaching beyond middle of pronotum. Antennal club weakly flattened. Supraocular line absent.

Anterior angles of pronotum well developed, with tooth. Lateral margin of pronotum sinuous, with teeth. Dorsal punctation depressed and dense, with short pubescence. Pronotal pits absent. Procoxal cavity open behind. Width of mesoventral process narrower than mesocoxa. Submesocoxal lines absent. Tarsi without lobes beneath. Tibial spurs not visible (or absent, or poorly developed).

Tarsal structure slightly noticeable, tarsal formula seemingly 5-5-5. Length of tarsomere 1 equal to tarsomere 2.

Scutellum transverse. Elytral punctation striate. Elytra narrowly explanate. Humeral spine absent. Epipleuron complete to apex of elytron.

Abdominal ventrites 1 and 2 free.

Externally may be confused with some members of the genus Dapsa Latreille, 1829, however, there are clear differences [Audisio, De Biase, 1996]. Audisio and De Biase [1996] concluded that the genus Dapsa based on the following characters: more or less distinctly curved median connection between caudal mesocoxal marginal lines; elytral margins not visible from above; elytra disorderly punctured. New taxon has different characters. Pronotum close similar to genus Henotimorphus.

\section{Serramorphus rasnitsyni sp.n.}

Figs $1-4$

MATERIAL. Holotype: CCHH 26-4, Bitterfeld, Late Eocene. Type disposal: Material and types will be deposited at the amber collection of Senckenberg Deutsches Entomologisches Institut Müncheberg (SDEI), Germany. Collection code: CCHH.

DESCRIPTION. Body elongate-oval, length $2.8 \mathrm{~mm}$. Head and pronotum with very short hairs. Size of eye less than half length of head. Diameter of facet equal to $0.001 \mathrm{~mm}$. Shape of eye hemispherical. Punctuation of head: punctures medium in size, distance between neighbouring punctures equal to one diameter of puncture.

Pronotal width to length ratio 1.7 . Width of pronotum greater than its length, not narrower than the combined width of the elytra. Anterior margin of pronotum without deep excavation, only slightly sinuated. Lateral margins are slightly narrowed apically and basally. Punctuation with mediumsize punctures, the distance between them is one diameter of puncture. Length of pronotum relative to length of elytra 0.4. Posterior angles right, basal edge sinuated. Basal groove pronounced, wide. Middle coxae close together, posterior coxae separated from each other by a distance of more than 1 diameter coxa. Pronotal carina relatively thick.

Legs slender, length of posterior tarsus shorter than length of posterior tibia. Legs slender, tarsi with long segments without lobes, tarsal formula 5-5-5. At the apical joint of two slender large claws without processes.

Elytral pubescence short, rare, accumbent. Length of hair less than breadth of scutellum. Elytra covered by closely spaced rows of punctures, distance between neighbouring punctures equal to one diameter of puncture, points longitudinally elongated. Points on pronotum less than on disc of elytra.

Elytral length 1.4 times greater than width. Tooth on schoulder absent. Sutural stria extending beyond the middle of the disk. Epipleuron visible from above.

DISTRIBUTION. This is the first discovery of an exotic erotylid genus in Europe in the fossil state. Previous findings belonged to genera with a much broader distributional relationships. But Thallisellini occurs in Neotropic realm.

The fauna of Bitterfeld, like other Late Eocene ambers, is dominated by Holarctic elements; thus, in the well-studied and representative collection of Saxon amber, Holarctic species dominate in the number of specimens which is twice that of tropical species, although the number of Holarctic species is lower [Perkovsky, 2016]. Bitterfeld amber occupies an intermediate position between the Baltic amber from Gdańsk Bay and southern Danish and Rovno ambers in the ratio of the Holarctic and tropical species. By studing isotopic results are broadly representative of both deposits, Wolfe et al. [2016] predict that Bitterfeld amber should contain a greater overall proportion of warm stenothermous arthropods relative to Baltic amber. Therefore, the finding of the representative of Thalisellini in Bitterfeld amber as well as former finding phalacrid Neolitochropus Lyubarsky et Perkovsky, 2016 from tropical group are additional arguments that support this hypothesis.

The new species is the $15^{\text {th }}$ species of beetles known from Bitterfeld amber, and $7^{\text {th }}$ known only from Bitterfeld [Alekseev, 2015]. The genus Serramorphus gen.n. is the fourth monotypic genus of beetles known only from Bitterfeld amber (the other two genera belong to long-horned beetles, and shining flower beetles).

BIOLOGY. On the biology of the tribe Thallisellini little is known. Species of Platoberus appear to be commonly collected in rotting vegetation and leaf litter and Thallisella is primarily associated with live vegetation. Members of Acryptophagus have been taken by beating vegetation.

Although reliable data on biology of Serramorphus gen.n. are absent, an analysis of some structural features of the beetle allows to make some conclusions. If reconstruction of [Leschen, Buckley, 2007] of the primary diet of Erotylidae is true, 

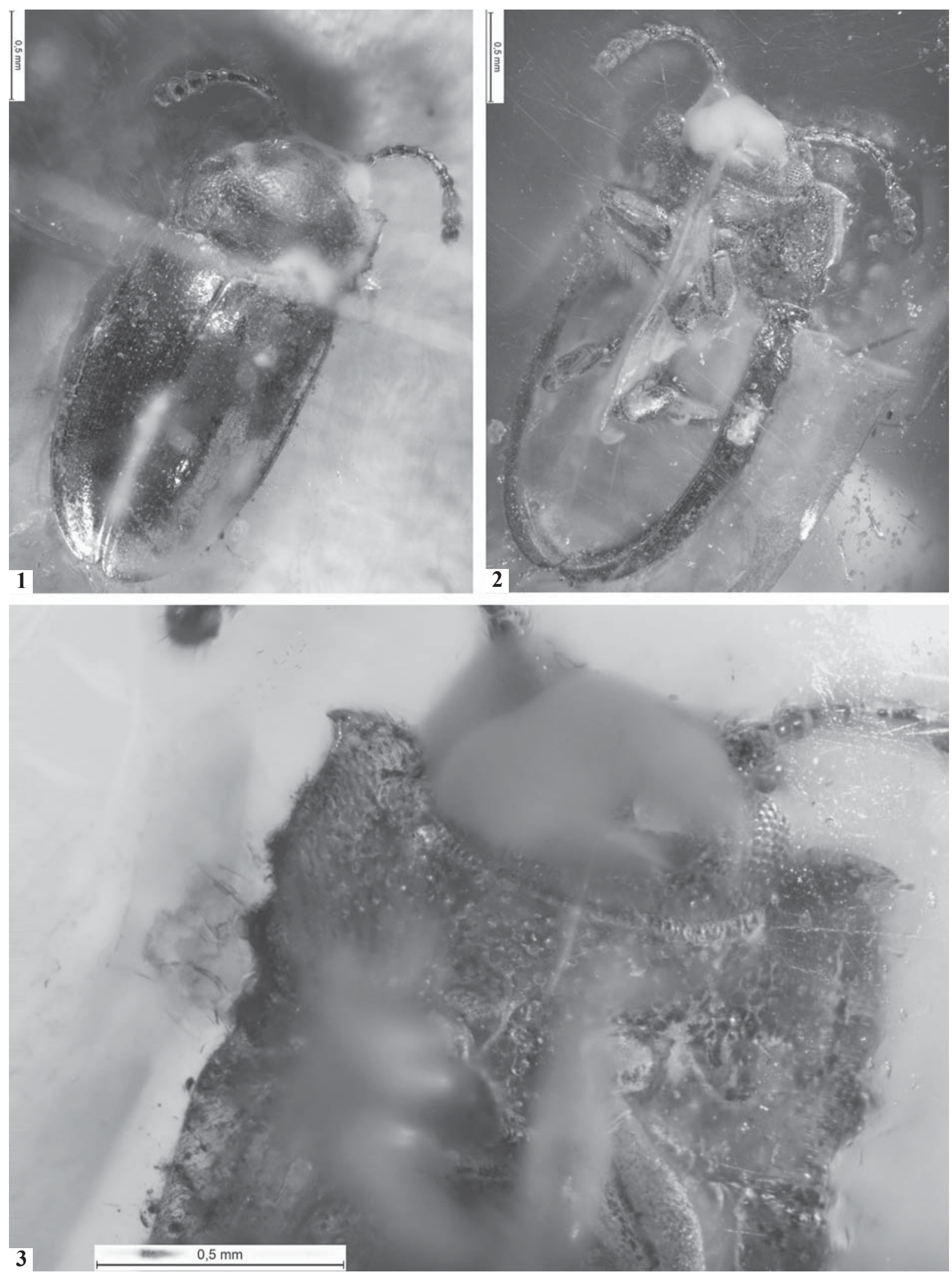

Figs. 1-3. Holotype Serramorphus rasnitsyni gen.n., sp.n., dorsal habitus, photo: 1 - dosal view; 2 - ventral view; 3 - ventral view, detailed, lateral margin of pronotum.

Рис. 1-3. Голотип Serramorphus rasnitsyni gen.n., sp.n., фотография: 1 - сверху; 2 - снизу; 3 - снизу, детально боковой край переднеспинки. 


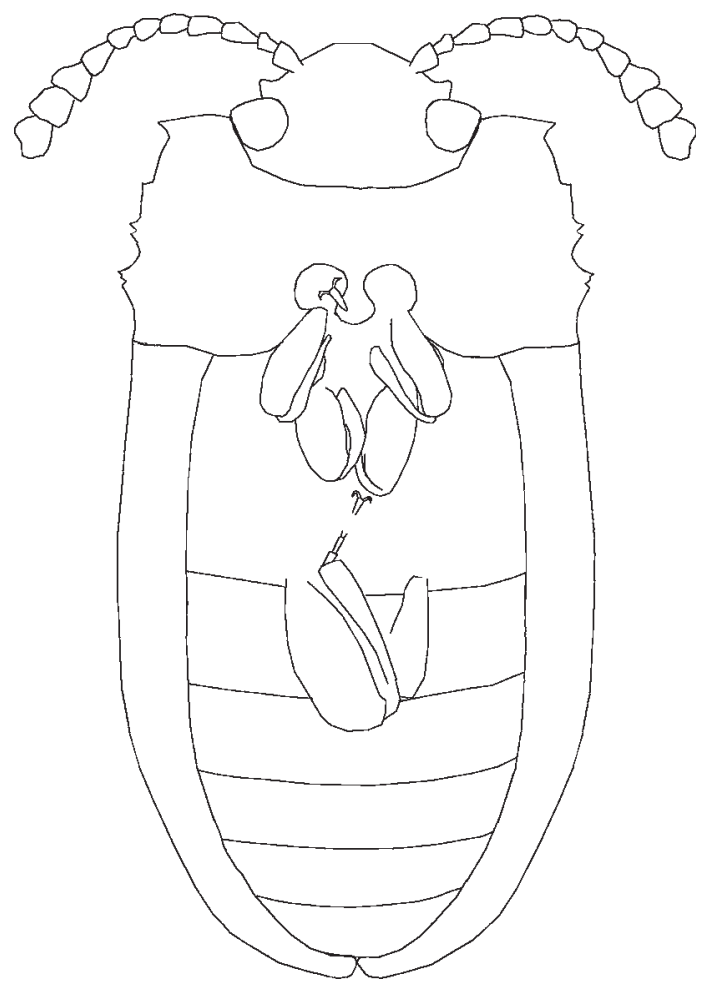

Fig. 4. Holotype Serramorphus rasnitsyni gen.n., sp.n., ventral view, drawing.

Рис. 4. Голотип Serramorphus rasnitsyni gen.n., sp.n., вид снизу, реконструкция.

we should assume that the new genus, placed at the middle of the erotylid tree, was characterized by microfungal feeding or saprophagy. tsyn.

ETYMOLOGY. Named in honour of Prof. A.P. Rasni-

\section{Key to Genera of the ERotylidae}

(according to Leschen, 2003) for those having well-developed of anterior angle of pronotum, elytra with rows of puncture, ventrite I and II free.

1. Basal groove of pronotum broad

2

- Basal groove of pronotum narrow or absent. Supraocular

line absent

3

2. Supraocular line present. Acryptophagus Grouvelle, 1919

- Supraocular line absent ............... Serramorphus gen.n.

3. Anterior angles of pronotum more or less well developed; body more or less convex; subocular bead present. Antennal club 3-, 4- or 5-segmented......... Thallisella Crotch, 1875

- Pronotal callosity absent, anterior angles poorly developed; body dorsoventrally compressed; subocular bead absent Platoberus Sharp, 1900

ACKNOWLEDGMENTS. We are grateful to Christel and Hans Werner Hoffeins (Hamburg, Germany) for providing the material. We would like to thank to Vitaly I. Alekseev (Kaliningrad State Technical University, Russia) for information on the Bitterfeld amber beetles, Vitaly Yu. Nazarenko (Schmalhausen Institute of Zoology, Kiev, Ukraine) for help with photos. The work has been supported by a grant AAAAA16-116021660077-3.

\section{References}

Alekseev V.I. 2014. A new species of Triplax Herbst, 1793 (Coleoptera: Erotylidae) from Bitterfeld amber // Baltic J. Coleopterol. Vol.14. No.2. P.171-177.

Alekseev V.I. 2015. Preliminary linguistic classification of Latin specific epithets for beetles (Insecta: Coleoptera) from Eocene amber of Central Europe// Zool. and Ecol. Vol.25. No.4. P.373376.

Archibald S.B., Mathewes R.W. 2000. Early Eocene insects from Quilchena, British Columbia, and their paleoclimatic implications // Can. J. Zool. Vol.78. P.1441-1462.

Audisio P., De Biase A. 1996. Taxonomic revision, phylogeny and biogeography of the beetle genus Dapsa Latreille (Coleoptera: Endomychidae). // Mem. Soc. Entomol. Ital. Vol.74. P.65-130.

Kirejtshuk A.G., Azar D. 2013. Current knowledge of Coleoptera (Insecta) from the Lower Cretaceous Lebanese amber and taxonomical notes for some Mesozoic groups // Terrestrial Arthropod Reviews. Vol.6. No.1-2. P.103-134.

Leschen R.A.B. 2003. Erotylidae (Insecta: Coleoptera: Cucujoidea): Phylogeny and review // Fauna of New Zealand. Vol.47. P.1-108.

Leschen R.A.B. 2006. Evolution of Saproxylic and Mycophagous Coleoptera in New Zealand // S.J. Grove, J.L. Hanula (eds.). Insect biodiversity and dead wood: proceedings of a symposium for the 22nd International Congress of Entomology. Gen. Tech. Rep. SRS-93. Asheville, NC: U.S. Department of Agriculture, Forest Service, Southern Research Station. P.1-8.

Leschen R.A.B., Buckley T.R. 2007: Multistate Characters and Diet Shifts: Evolution of Erotylidae (Coleoptera) // Syst. biol. Vol.56. P.97-112.

Leschen R.A.B., Wegrzynowicz P. 1998. Generic Catalogue and Taxonomic Status of Languriidae (Cucujoidea) // Ann. Zool. (Warszawa). Vol.48. Nos3-4. P.221-243.

Lyubarsky G.Yu., Perkovsky E.E. 2012. A new genus of Erotylidae from Eocene amber (Coleoptera: Clavicornia) // Russian Entomol. J. Vol.21. No.1. P.35-38.

Lyubarsky G.Yu., Perkovsky E.E. 2016. A new genus Neolitochropus (Coleoptera: Cucujoidea: Phalacridae) from Late Eocene Bitterfeld Amber // Russian Entomol. J. Vol.22. No.3. P.249-253.

Lyubarsky G.Yu., Perkovsky E.E., Alekseev V.I. 2016. The First Record of the Subfamily Xenoscelinae (Coleoptera, Erotylidae) from the Baltic Amber // Paleontol J. Vol.50. No.9. P.1-7.

Perkovsky E.E. 2016. Tropical and Holarctic ants in Late Eocene ambers // Vestnik zoologii. Vol.50. No.2. P.111-122.

Poinar G.O. 1992. Life in Amber. Stanford: Stanford University Press. XIII + $350 \mathrm{pp}$.

Robertson J.A., McHugh J.V., Whiting M.F. 2004. A molecular phylogenetic analysis of the pleasing fungus beetles (Coleoptera: Erotylidae): evolution of colour patterns, gregariousness and mycophagy // Syst. Entomol. Vol.29. P.173-187.

Skelley P.E. 1997. A new species of Dacne Latreille from Dominican amber, with a key and checklist to known species of Dacne (Erotylidae: Dacninae) // Ann. Zool. Vol.47. Nos.1-2. P.49-53.

Spahr U. 1981a. Bibliographie der Berstein- und Kopal-Käfer (Coleoptera) // Stuttg. Beitr. Naturk., Ser. B (Geol. u. Paläontol.). Bd.72. S.1-21.

Spahr U. 1981b. Systematischer Katalog der Berstein- und KopalKäfer (Coleoptera) // Stuttg. Beitr. Naturk., Ser. B (Geol. u. Paläontol.). Bd.80. S.1-107.

Węgrzynowicz P. 2002. Morphology, phylogeny and classification of the family Erotylidae based on adult characters (Coleoptera: Cucujoidea) // Genus. Vol.13. No.4. P.435-504.

Węgrzynowicz P. 2007. Family Erotylidae Latreille, 1802 // I. Löbl, A. Smetana (eds.) Catalogue of Palaearctic Coleoptera. Vol.4. Stenstrup: Apollo Books. 935 pp.

Windsor D., Ness J., Gomez L.D., Jolivet P. 1999. Species of Aulacoscelis Duponchel and Chevrolat (Chrysomelidae) and Nomotes Gorham (Languriidae) feed on fronds of Central American Cycads // Coleopterists Bull. Vol.53. No.3. P.217-231.

Wolfe A.P., McKellar R.C., Tappert R., Sodhi R.N.S., Muehlenbachs K. 2016. Bitterfeld amber is not Baltic amber: Three geochemical tests and further constraints on the botanical affinities of succinite // Rev. Palaeobot. Palynol. Vol.225. P.21-32. 